\title{
Memahami Hukuman Salib dalam Perspektif Intertestamental sampai dengan Perjanjian Baru
}

\author{
Yonatan Alex Arifianto ${ }^{1}$, Joseph Christ Santo 2 \\ ${ }^{1}$ Sekolah Tinggi Teologi Sangkakala, Salatiga, Jawa Tengah \\ ${ }^{2}$ Sekolah Tinggi Teologi Berita Hidup, Karanganyar, Jawa Tengah \\ 1arifianto.alex@gmail.com,2jx.santo@gmail.com
}

\begin{abstract}
The crucifixion of Jesus in Golgotha is an event that has an important significance in Christianity. But little is known about how crucifixion could have taken place in a Jewish environment where the matter of crucifixion was never mentioned expensively in the Old Testament. This paper intends to answer questions about the history of the penalty of the cross from the Intertestamental era to the crucifixion experienced by Jesus during the New Testament. Through literature studies, it was revealed that the punishment of the cross came from Persia adopted by the Greeks, and the Romans continued it as a punishment for the rebels by making the prisoners suffered greatly before his death. For Christianity, the punishment of the cross experienced by Jesus has more meaning than the punishment carried out by innocent people, that is as a substitute punishment that should be experienced by sinful humans.
\end{abstract}

Keywords: cross; crucifixion; intertestament; New Testament

\begin{abstract}
Abstrak: Penyaliban Yesus di Golgota merupakan peristiwa yang memiliki makna penting dalam kekristenan. Namun tidak banyak diketahui bagaimana penyaliban bisa terjadi di lingkungan bangsa Yahudi yang mana hal penyaliban tidak pernah disebut secara ekspilis dalam kitab Perjanjian Lama. Tulisan ini bermaksud menjawab pertanyaan mengenai sejarah hukuman salib sejak era Intertestamental hingga penyaliban yang dialami oleh Yesus pada masa Perjanjian Baru. Melalui studi pustaka dikemukakan bahwasanya hukuman salib berasal dari Persia yang diadopsi oleh bangsa Yunani, dan bangsa Romawi meneruskannya sebagai hukuman bagi para pemberontak dengan membuat pesakitan sangat menderita sebelum kematiannya. Bagi kekristenan, hukuman salib yang dialami Yesus memiliki makna lebih dari sekadar hukuman yang ditangung oleh orang yang tidak bersalah, yaitu sebagai hukuman penganti yang seharusnya dialami oleh manusia yang berdosa.
\end{abstract}

Kata kunci: intertestamen; penyaliban; Perjanjian Baru; salib

\section{INTRODUCTION}

Peristiwa penyaliban Yesus di Bukit Golgota, bagi orang Kristen, dipandang sebagai peristiwa yang ajaib sebagaimana dikisahkan di dalam Alkitab (Yoh. 19:17), namun peristiwa ini juga membuat orang menyadari bahwa proses penyaliban begitu mengerikan dan terlalu kejam. Penyaliban sendiri memiliki sejarah yang cukup kelam sebagai hukuman bagi orang yang memberontak terhadap pemerintahan atau para penjahat yang diadili karena menjadi pengacau masyarakat. Peter Walker mengungkapkan, bahwa penyaliban merupakan bentuk hukuman yang digunakan oleh pemerintahan Romawi untuk dua golongan atau kelas masyarakat yang paling rendah yaitu budak dan penjahat, khususnya 
orang-orang yang memberontak terhadap pemerintahan Romawi. ${ }^{1}$ Hukuman salib atau penyaliban yang dilakukan Kekaisaran Romawi terhadap Yesus dan kedua penjahat merupakan cara hukuman yang kejam, mengerikan, yang dilakukan oleh bangsa di luar Yahudi. Fakta ini sekaligus menunjukkan bahwa penyaliban itu adalah bukti adanya hukuman mati yang berlangsung di wilayah jajahan Romawi. Penyaliban yang diterapkan merupakan salah satu bentuk eksekusi hukuman mati pada saat itu.

Efek penyaliban yang diharapkan bukanlah kematian itu sendiri, melainkan penderitaan saat menjelang kematian. Sejalan dengan itu Zaluchu mengungkapkan, bahwa salib sebagai bentuk hukuman mati perlahan-lahan yang sangat menyiksa membawa dampak secara fisik pada terhukumnya. ${ }^{2}$ Dari penderitaan akibat penyaliban tersebut, sejatinya kematian merupakan suatu hal yang sangat diinginkan oleh orang yang disalib. Ketika ada di atas kayu salib, Yesus mengatakan, "Allahku, Allahku mengapa Engkau meninggalkan Aku?" (Mat. 27:46). Perkataan ini menyiratkan keberadaan Yesus sebagai manusia yang merasakan begitu berat penderitaan yang dialaminya. Penyaliban itu sendiri adalah salah satu bentuk hukuman yang sangat menyiksa, dibandingkan dengan hukuman mati lainnya. Hukuman gantung, membakar manusia, suntik mati, tembak mati, atau pancung hanya membutuhkan waktu beberapa detik saja menjelang kematian, namun penyaliban membutuhkan waktu dan proses kematian yang menyakitkan bagi terhukumnya.

Di sisi lain, kini salib menjadi simbol Kristen yang sangat khas bagi kekristenan, dan salib adalah kebanggaan orang percaya akan karya penebusan dan keselamatan yang dikerjakan Yesus di kayu salib. Salib juga memberikan makna yang besar bagi orang percaya sebagai simbol cinta Tuhan terhadap manusia. Bahkan lebih daripada itu, salib juga memiliki makna yang dapat membawa manusia datang kepada pengenalan akan Allah. Nilai pemberitaan salib sejatinya adalah kekuatan Allah yang dapat menyelamatkan (1 Kor. 1:19). Oswald Chambers menuliskan dampak salib adalah keselamatan, pengudusan, penyembuhan; dan masih banyak lagi dampak salib bagi umat manusia. ${ }^{3}$ Karena itu rasul Paulus sangat menghormati dan bangga atas apa yang dikerjakan Yesus Kristus dalam penyelamatan melalui karya salib (Gal. 6:14).

Salib sebagai simbol dan identitas kekristenan bisa dilihat dalam ornamen-ornamen kebesaran orang percaya. Namun, simbol salib bagi kekristenan bertolak belakang dengan cara dan kejadian dimasa lampau, yang dianggap sebagai suatu cara menghukum yang mengerikan dan merendahkan seseorang. ${ }^{4}$ Dengan demikian sepanjang sejarah salib telah mengalami ambivalensi makna. Salib menjadi tanda kehinaan dan keagungan, salib menjadi tanda ketaklukkan tetapi juga tanda penaklukan, dan salib menjadi sesuatu yang sakral dan dikasihi tetapi juga mengalami desakralisasi dan dibenci. ${ }^{5}$

\footnotetext{
${ }^{1}$ Peter Walker, In The Steps of Jesus (Yogyakarta: Kanisius, 2010), 177.

${ }^{2}$ Sonny Eli Zaluchu, "Penderitaan Kristus sebagai Wujud Solidaritas Allah Kepada Manusia," DUNAMIS: Jurnal Teologi dan Pendidikan Kristiani 2, no. 1 (2017): 61-74, www.sttintheos.ac.id/ejournal/index.php/dunamis.

${ }^{3}$ Oswald Chambers, Pengabdianku Bagi KemuliaanNya (Jakarta: Duta Harapan Dunia, 2003), 26.

${ }^{4}$ Pr. V. Indra Sanjaya, Yesus, Orang Nazaret, Raja Orang Yahudi (Yogyakarta: Kanisius, 2004), 8687.

${ }^{5}$ Andreas Anangguru Yewangoe, Agama dan Kerukunan (Jakarta: BPK Gunung Mulia, 2009), 224.
} 
Menelisik ke belakang dari zaman Perjanjian Lama sampai zaman Perjanjian Baru yang terdapat dalam catatan Alkitab, dapat dipastikan bahwa hukuman salib yang diterapkan oleh Romawi dengan memaku kaki dan tangan ini tidak digunakan dan diperintahkan untuk menghukum orang yang bersalah oleh raja atau pemerintahan Israel. Namun Alkitab menuliskan adanya hukuman yang menghilangkan nyawa atau hukuman mati. Menurut hukum Musa atau Taurat hukuman mati dilakukan dengan menggunakan pedang (Kel. 21), dibakar (Im. 20:14), dan dirajam dengan batu (Ul. 21:21). Hukuman mati yang sudah dilaksanakan terhadap pelaku kejahatan tidak diperbolehkan mayatnya digantung semalam-malaman.

Penyaliban tidak pernah dimasukkan ke dalam tata cara dan hukum Yahudi sebagai sarana untuk menghukum orang. ${ }^{6}$ Namun, Yesaya menubuatkan bagaimana sang Mesias berada di antara pemberontak (Yes. 53:12), dan hal itu tergenapi dalam penyaliban Yesus dengan adanya dua penjahat yang juga ikut disalib (Mark. 15:7, 28). Rasul Paulus menyatakan, bahwa kematian Yesus, kebangkitan, maupun Yesus naik ke surga adalah penggenapan kitab suci (1 Kor. 15:3-4).

Tujuan dari penelitian ini adalah menjawab pertanyaan, bagaimanakah hukuman salib dalam perspektif Intertestamental sampai dengan Perjanjian Baru dapat diuraikan secara lugas; dan bagaimana makna penyaliban Yesus bagi kekristenan.

\section{METODE}

Untuk menjawab pertanyaan topik tersebut penelitian ini menggunakan metode pustaka dengan pendekatan kualitatif deskriptif. ${ }^{7}$ Penekanannya adalah pada kajian sejarah terhadap sumber-sumber pustaka dan mengurainya serta memberi penjelasan dalam sebuah kerangka uraian. Analisis dan studi terminologi hukuman salib dalam tinjauan masa intertestamental sampai pada perjanjian baru dan kajian dipusatkan pada penggalian sejarah hukuman salib. Sumber utama adalah literasi pustaka yang mengkaji secara luas tentang hukuman salib yang dilengkapi oleh berbagai artikel jurnal dan sumber akademik lainnya yang relevan dengan topik yang dibahas. Hasil penelitian disajikan oleh penulis secara deskriptif.

\section{PEMBAHASAN}

\section{Penyaliban Masa Intertestamental}

Dalam istilah teologi, masa intertestamental dikenal sebagai suatu masa yang berada di antara Perjanjian Lama dan Perjanjian Baru. Masa ini kadang-kadang disebut masa sunyi.

\section{Penyaliban pada Masa Kerajaan Persia}

Penyaliban mungkin pertama kali diperkenalkan oleh orang-orang dari kerajaan Persia. Pada awalnya pelaku tindak kriminal diikat pada sebuah pohon atau dipakukan pada sebuah tiang yang tegak, dengan kaki masih dapat menyentuh ke tanah. Kemudian ada

\footnotetext{
${ }^{6}$ V. Indra Sanjaya, Yesus, Orang Nazaret, Raja Orang Yahudi, 86.

${ }^{7}$ Sonny Eli Zaluchu, "Strategi Penelitian Kualitatif dan Kuantitatif di Dalam Penelitian Agama," Evangelikal: Jurnal Teologi Injili dan Pembinaan Warga Jemaat 4, no. 1 (2020): 28-38.
} 
variasi perkembangan dengan menggantungkan pelaku di atas palang atau media yang dipakai mengantung pelaku. Hukuman gantung menjadi tradisi kerajaan Persia yang menganggap bahwa tanah mereka suci, sehingga mereka tidak menginginkan tanah mereka tercemari dengan kejahatan-kejahatan yang berkeliaran di sekitar mereka. ${ }^{8}$ Indra Sanjaya menyatakan bahwa bangsa Persia dan Media memiliki kebiasaan menghukum dengan penyaliban, karena cara ini dipilih agar tidak mengotori bumi yang sudah dipersembahkan kepada Ahuramazda (Ormuz) yang merupakan dewa tertinggi Persia. ${ }^{9}$

\section{Penyaliban pada Masa Kerajaan Yunani}

Setelah menginvasi Persia, Alexander Agung memperkenalkan bentuk hukuman salib ini di Mesir dan Kartago. ${ }^{10}$ Namun penemuan arkeologi juga membuktikan bahwa hukuman penyaliban digunakan di Athena, Yunani pada abad ke-7 SM untuk menghukum mati para perampok. ${ }^{11}$

\section{Penyaliban pada Masa Kekaisaran Romawi}

Hukuman gantung di Romawi ditiru dari tradisi kerajaan Persia ${ }^{12}$, tetapi Romawi tidak langsung mewarisinya dari Persia. Kekaisaran Romawi mengadopsi hukuman kejam dan mengerikan itu dari Kartago, di mana Aleksander Agung telah mengadopsi hukuman ini dari Persia dan menerapkannya di Kartago.

Meskipun Kekaisaran Romawi bukan pencipta metode itu, mereka menyempurnakan bentuk penyiksaan hukuman mati yang dirancang dengan sengaja untuk menghasilkan kematian secara perlahan-lahan dan merasakan nyeri kesakitan yang penuh penderitaan. ${ }^{13}$ Selanjutnya Kekaisaran Romawi menerapkan penyaliban sebagai bentuk hukuman mati. Witness Lee mengungkapkan bahwa penyaliban adalah salah satu macam hukuman terkejam yang dilaksanakan oleh pemerintahan kekaisaran Romawi pada masa itu. ${ }^{14}$ Para penjahat disalib atau digantung supaya tanah yang merupakan milik dewa tidak dinajiskan. $^{15}$

Pada masa ini ada pemberontak-pemberontak dari orang Yahudi yang melakukan perlawanan kepada kekaisaran Romawi, terutama perlawanan secara politik. Pernah ada penyaliban yang dilakukan secara besar-besaran oleh Jenderal Crassus yang menghukum pemberontak dengan hukuman salib. Sekitar enam ribu orang pemberontak di bawah pimpinan Spartakus pada tahun 71 SM menerima hukuman salib karena terlibat dalam pemberontakan itu. ${ }^{16}$ Bahkan pemberontakan terus berlanjut sampai tahun 60 Masehi.

${ }^{8}$ Elson Lingga, Firman Hidup 69 (Jakarta: BPK Gunung Mulia, 2008), 36.

${ }^{9} \mathrm{~V}$. Indra Sanjaya, Yesus, Orang Nazaret, Raja Orang Yahudi, 85.

${ }^{10}$ Zaluchu, "Penderitaan Kristus sebagai Wujud Solidaritas Allah Kepada Manusia."

${ }^{11}$ Luis M. Bermejo, Selubung Kirmizi Jejak-Jejak Penyaliban Al Masih (Yogyakarta: Kanisius, 2008), 229.

${ }^{12}$ Lingga, Firman Hidup 69, 36

${ }^{13}$ Zaluchu, "Penderitaan Kristus sebagai Wujud Solidaritas Allah Kepada Manusia."

${ }^{14}$ Witness Lee, Garis-garis Besar Injil 1 (Surabaya: Yayasan Perpustakaan Injil, 2001), 34.

${ }^{15}$ William Barclay, Pemahaman Alkitab Setiap Hari: Injil Matius Pasal 11-28 (Jakarta: BPK Gunung Mulia, 2009), 577.

${ }^{16}$ Walker, In The Steps of Jesus, 176. 
Tercatat bahwa pada tahun 4 Masehi kekaisaran Romawi mengeksekusi pemberontakan yang terjadi di Palestina dan Yudea dengan hukuman salib. ${ }^{17}$

\section{Penyaliban dalam Pandangan Orang Yahudi}

Salib dilambangkan sebagai penolakan bumi dan surga. Dalam kepercayaan Israel, seperti yang diungkapkan oleh Elson Lingga, orang yang dihukum tergantung atau disalib tidak lagi mempunya status, dia dan arwahnya mengambang dan tidak mempunyai harapan lagi. Tanah tidak tercemar karena kejahatannya dan surga tidak menerimanya karena akan mencemari jubah kekudusan para pengisi surga. ${ }^{18}$ Hukuman gantung ini juga pernah diniatkan Haman untuk menghukum seorang Yahudi yaitu Mordhekai pada tiang sulaan yang tingginya lima puluh hasta (Ester 5:14) ketika raja Ahasyweros memerintah Persia dan Media. Penyaliban adalah peringatan bagi pemberontak maupun orang yang tidak sejalan dengan pemerintahan, baik pada masa kerajaan Media dan Persia, dan berlanjut sampai pada kekaisaran Romawi.

Dalam zaman kekaisaran Romawi penyaliban merupakan bentuk hukuman kuno dan cara menghukum para penjahat. ${ }^{19}$ Hukuman Salib merupakan hukuman memalukan dalam budaya dan nilai norma agama Yahudi sebab dalam Alkitab Perjanjian lama ada pemahaman bahwa orang yang mengalami kematian “ diatas pohon"adalah orang yang mendapat kutukan dari Allah (Ul. 21:23). Dan ketelanjangan dari proses hukuman salib adalah hal memalukan karena penyaliban dalam prosesnya menelanjangi terdakwa. ${ }^{20}$ Sependapat dengan itu Luis Menyatakan umat manusia tidak merasa nyaman tentang visualisasi kekerasan penyaliban Romawi dalam segala kebrutalannya terutama ketelanjangan si korban. ${ }^{21}$ Hadirnya narasi penyaliban yang menyakitkan secara fisik maupun psikis Elson Lingga berpendapat Bahwa: kematian diatas salib sangat menyakitkan dan mengerikan, bahkan orang romawi sendiri memandang dengan gemetar dan ketakutan. ${ }^{22}$ Cara penyaliban ini adalah metode eksekusi hukuman mati yang paling kejam dan memalukan bagi terdakwa dan generasi keturunannya yang mengalaminya. ${ }^{23}$ Sehingga penyaliban bagi warga negara Romawi merupakan tindakan hukuman yang ilegal. ${ }^{24}$

\section{Penyaliban Yesus dalam Pandangan Kristen}

\section{Penyaliban Adalah Hukuman bagi Pemberontak}

Pada zaman kekaisaran Romawi menjajah Israel, hukuman penyaliban terus dilakukan oleh pemerintahan kekaisaran Romawi termasuk pada hukuman bagi orang yang tidak bersalah namun didakwa, yaitu Yesus. Hukuman penyaliban terhadap Yesus Kristus dan kedua orang penjahat merupakan penyaliban yang paling terkenal. Kejadian hukuman yang kontroversi dari penyaliban atas dakwaan Ahli Taurat dan orang Yahudi mengakibatkan Yesus

\footnotetext{
${ }^{17}$ Ibid., 177.

${ }^{18}$ Lingga, Firman Hidup 69, 38.

${ }^{19}$ Bermejo, Selubung Kirmizi Jejak-Jejak Penyaliban Al Masih, 229.

${ }^{20}$ Walker, In The Steps of Jesus, 177.

${ }^{21}$ Bermejo, Selubung Kirmizi Jejak-Jejak Penyaliban Al Masih, 14.

${ }^{22}$ Lingga, Firman Hidup 69, 36.

${ }^{23}$ John Stott, Kristus yang Tiada Tara (Surabaya: Momentum, 2013), 17.

${ }^{24}$ Barclay, Pemahaman Alkitab Setiap Hari: Injil Matius Pasal 11-28, 577.
} 
harus disalib. Sependapat dengan hal itu Tissa Balasuriya mengatakan Yesus tidak menentang kekaisaran maupun sistem pemerintahan Romawi. ${ }^{25}$ Yesus bukanlah pemberontak bersenjata seperti pemberontak kaum Zelot dan Ia juga bukan konformis yang memihak kepada Romawi seperti kaum Herodian atau orang-orang munafik seperti para farisi yang dalam teori menentang sitem pajak namun pada praktiknya membayar pajak itu. ${ }^{26}$ Tapi kenyataannya Yesus harus menjalani hukuman salib itu dengan siksaan dan aniaya. Hukuman sesah atau Verberatio merupakan kebiasaan kekaisaran Romawi dan selalui mendahului penyaliban. ${ }^{27}$

Penyaliban yang terjadi semestinya diperuntukkan bagi para pemberontak dan pelaku kriminal yang dihukum dengan cara disalib, namun Yesus harus menggenapkan seluruh nubuatan kitab Perjanjian Lama yang harus mati di antara pemberontak (Yes. 53:12), dan menggenapi tentang kematian Yesus yang harus ditusuk kaki dan tangan-Nya, (Mzm. 22:17). Sejatinya penyaliban Yesus merupakan pemenuhan nubuatan Yesaya, bahwa janji keselamatan yang dinyatakan Allah lewat pribadi seorang hamba Tuhan yang menderita (Yes. 53:1-7) ${ }^{28}$ Dan penyaliban Yesus adalah bagian rencana Allah bagi Mesias. ${ }^{29}$

Yesus sebagai bagian masyarakat harus tunduk pada hukum untuk diadili, Ia harus mengalami proses pengadilan menurut hukum Romawi yang pertama Yesus diadili di hadapan gubernur Kekaisaran Romawi, yakni Pontius Pilatus, Yesus dituduh oleh para ahli Taurat dan orang Yahudi melakukan pelanggaran dan pemberontakan politik dengan menyatakan sebagai Raja Orang Yahudi, hal itu bertentangan dengan hukum Romawi, namun pada realitanya Pilatus tidak menemukan kesalahan hukum maupun kesalahan administrasi. Pilatus menyimpulkan bahwa meskipun Yesus dibawa di hadapannya karena dianggap menyesatkan orang banyak dan menghasut mereka untuk memberontak terhadap Romawi, ia tidak menemukan kesalahan apapun pada diri Yesus (Luk. 23:14) ${ }^{30}$. Lalu Pilatus memberikan wewenang terhadap Herodes karena Yesus berasal dari kota Galilea.

Herodes saat itu yang memerintah daerah Galilea juga tidak mendapati kesalahan ataupun dakwaan yang harus dijatuhi hukuman maka Herodes kembali mengirimkan kepada Pilatus. Alkitab mencatat Pilatus membasuh tangannya sebagai simbol tidak bertanggung jawab terhadap keputusan yang diberikan kepada Yesus (Matius 27 : 24). Penyaliban yang di prakasai oleh dorongan orang Yahudi dan para ahli Taurat memaksa Pilatus mengeluarkan keputusan untuk menyalibkan Yesus, hukuman mati itu divonis oleh perintah gubernur Kekaisaran Romawi untuk provinsi Yudea, yakni Pontius Pilatus atas dasar dakwaan para Ahli Taurat mengenai pemberontakan Yesus dan atas pengakuanNya sebagai raja orang Yahudi. Hal ini mengindikasikan dengan jelas bahwa Gubernur romawi

\footnotetext{
${ }^{25}$ Tissa Balasuriya, Teologi Siarah (Jakarta: BPK Gunung Mulia, 2004), 192.

${ }^{26}$ Ibid., 194.

${ }^{27}$ J.T. Nielsen, Tafsiran Alkitab: Kitab Injil Matius 23-28 (Jakarta: BPK Gunung Mulia, 2009), 151.

${ }^{28}$ Lingga, Firman Hidup 69, 40.

${ }^{29}$ Dianne Bergant dan Robert J. Karris, Tafsir Alkitab Perjanjian Baru (Yogyakarta: Kanisius, 2002),

${ }^{30}$ Walker, In The Steps of Jesus, 178.
} 75. 
Pontius Pilatus takut terhadap Yesus karena ajaran dan popularitasnya. Dan Pontius Pilatus juga andil dalam penyiksaan dan penganiayaan Yesus (Mat. 27:1, 31; Mrk. 15:16-20). ${ }^{31}$

Sejarah penyaliban Yesus, pelaku kriminal dan budak memberikan gambaran tentang hukuman penderitaan fisik dan psikis yang teramat kejam dan mengerikan. Seharusnya untuk hukuman dilakukan penghukuman dengan cara hukum Yahudi Yesus tidak di salib melainkan Yesus harus dirajam karena dakwaan kepada Yesus adalah penghujatan, akan tetapi penguasa kekaisaran Romawi tidak mengizinkan perajaman maka tindakan penggantinya adalah di siksa dan dipemalukan dengan cara diludahi lalu akhirnya di salib. ${ }^{32}$ Sebab wewenang untuk menjatuhkan hukuman mati pada zman itu ada di tangan penguasa kekaisaran Romawi. ${ }^{33}$ Pada masa itu tentara Romawi adalah yang paling kejam, sangat disiplin dan angkatan yang terkuat di dunia, yang menyiksa, meludahi maupun mengeksekusi penyaliban Yesus dan penjahat. ${ }^{34}$ Orang Yahudi sengaja "meminjam tangan" untuk mengeksekusi Yesus dengan hukuman mati yang sesuai dengan kesepakatan antara Pilatus dan Orang Yahudi terhadap darah yang tidak bersalah.

Sebelum penyaliban terhadap Yesus, di Palestina selama tahun 4 SM ada sekitar dua ribu orang menerima hukuman salib, ketika Varus jenderal Romawi menumpas pemberontakan yang dilakukan di Galelia. ${ }^{35}$ Sedangkan menurut Tacitus ahli sejarah Romawi, Penyaliban juga dikenal dikalangan orang Jerman dan juga orang Brinton namun yang paling kerap digunakan oleh orang Persia. Penyaliban membuat malu dan menderita serta kematian yang mengerikan adalah tujuan dari penyaliban yang dilakukan oleh orang diluar Yahudi. Namun kenyataannya berbeda Yoshepus menuliskan sejarah penyaliban oleh orang Yahudi ketika Imam Besar orang Saduki Alexander Janneus marah besar dan memerintahkan untuk menyalibkan dijalanan delapan ratus tawanan dan menyembelih para istri dan anak-anak dihadapan mereka. ${ }^{36}$ Hal penyaliban juga dapat diterapkan sesuai dengan Perjanjian Lama (Ul. 21:23) bagaimana hukuman mati menggantung yang dilakukan juga harus memiliki petunjuk pedoman pelaksanaan supaya tidak menjadi dosa dan menajiskan tanah milik pemberian Tuhan.

Pembunuhan terhadap orang Kristen bukan hal baru saat ini namun awal dari pergerakan orang percaya di Roma terjadi penyaliban dan pembunuhan yang dilakukan oleh Kaisar Nero dan Docletianus di zaman pemerintahnya. ${ }^{37}$ Hal itu terjadi tiga puluh lima tahun setelah Yesus disalibkan, banyak orang percaya yang harus mengalami siksaan salib akibat kebakaran hebat yang menghancurkan sebagaian kota Roma. Dan secara sembarangan mereka menuduh orang percaya kepada Yesus sebagai penyebab terjadinya

\footnotetext{
${ }^{31}$ Balasuriya, Teologi Siarah, 194.

${ }^{32}$ Trias Kuncahyono, Jerusalem 33 Imperium Romanum, Kota Para Nabi, dan Tragedi di Tanah Suci (Jakarta: Kompas Media Nusantara, 2011), 279.

${ }^{33}$ Bermejo, Selubung Kirmizi Jejak-Jejak Penyaliban Al Masih, 68.

${ }^{34}$ Jaerock Lee, Pesan Salib (Seoul: Urum Book, 2007), 34.

${ }^{35}$ Walker, In The Steps of Jesus, 177.

${ }^{36}$ Bermejo, Selubung Kirmizi Jejak-Jejak Penyaliban Al Masih, 229.

${ }^{37}$ Josef P. Widyamadja, Kebangsaan dan Globalisasi dalam Diplomasi (Yogyakarta: Kanisius, 2005), 135.
} 
kebakaran. ${ }^{38}$ Nero dalam rangka membersihkan kota Roma dari gelandangan dan perkampungan yang kotor, Nero memerintahkan membakar rumah yang dianggap tidak pantas di kota Roma dan kebakaran itu menimbulkan huru-hara sosial lalu sebagai jalan keluar penyelesaiannya dilimpahkan kepada orang Kristen yang tinggal di Roma sehingga kekejaman Nero terlampiaskan untuk membakar dan menyalibkan orang kristen. ${ }^{39} \mathrm{Hal}$ itu dikarenakan untuk mengelakan tuduhan atas dirinya dengan "mengkambinghitamkan" orangorang Kristen lalu menuduh merekalah yang memicu kebakaran tersebut. Akibatnya Nero bersumpah memburu dan membinasakan orang-orang kristen dengan menyalibkan dan membakar hidup-hidup serta memasukan orang kristen di kandang untuk dicabik-cabik binatang buas. ${ }^{40}$ Penyaliban kejam yang dilakukan Nero membuktikan bahwa proses kematian yang perlahan dan menderita tetap dipertahankan dalam kekaisaran Romawi sebagai tindakan menghukum pemberontak.

\section{Penyaliban Menjadi Penderitaan bagi Pesakitan}

Penyaliban sepanjang sejarah intertestamental sampai perjanjian baru mengalami modifikasi dan penyempurnaan untuk membuat si terhukum menderita dan juga mengalami penderitaan yang sangat menyakitkan. Setelah penangkapan dari malam sampai pagi Yesus tidak tidur dan mengalami kelelahan akibat intimidasi dan olok-olok tentara Romawi. Dalam penyaliban Yesus, penyesahan dengan mempermalukan sebagai bahan olok-olok. Setelah disiksa dan siap menjalani hukuman salib di bukit tengkorak, Yesus harus memikul salib-Nya (Mark. 15, 21). Sebenarnya peraturan bangsa Romawi mengharuskan sang terhukum sendiri memikul salibnya. Tetapi karena Yesus sudah kehabisan tenaga dan lemas dan dikawatirkan akan mati sebelum disalib maka para prajurit tentara kekaisaran Romawi mengambil suatu kebijakan lain (Markus 15). ${ }^{41}$

Jalan salib atau via dolorosa memberikan bukti penyiksaan Yesus bukan saja mempermalukan namun memberikan efek jera bagi setiap orang yang menontonnya ketika masyarakat jajahan Romawi berpikiran untuk memberontak kepada kekaisaran Romawi. Penyaliban dengan memakukan tangan dan kaki serta memberikan anggur asam adalah penderitaan yang panjang.

Penyaliban pada masa itu untuk mempercepat kematian supaya tidak menjadi hal yang menajiskan (Ul. 21: 23) dan menghormati hukum orang Yahudi maka prajurit kekaisaran Roma mematahkan kaki terlebih dahulu, supaya mempercepat kematiannya, dan ini diperlakukan buat kedua penjahat yang ada di samping kanan kiri Yesus. Sedangkan kaki dari TuhanYesus tidak sampai dipatahkan, sebab Yesus mati terlebih dahulu dari waktu yang diperhitungkan bagi orang yang terhukum salib, Sehingga membuat para perajurit kekaisaran Romawi tidak percaya akan apa yang telah terjadi dalam peristiwa penyaliban

\footnotetext{
${ }^{38}$ Bermejo, Selubung Kirmizi Jejak-Jejak Penyaliban Al Masih, 237.

${ }^{39}$ S. Wismoady Wahono, Di Sini Kutemukan: Petunjuk Mempelajari dan Mengajarkan Alkitab (Jakarta: BPK Gunung Mulia, 2009), 467.

${ }^{40}$ Kenneth Curtis, Stephen Lang, dan Randy Petersen, 100 Peristiwa Penting Dalam Sejarah Kristen (Jakarta: BPK Gunung Mulia, 2007), 2.

${ }^{41}$ V. Indra Sanjaya, Yesus, Orang Nazaret, Raja Orang Yahudi, 86.
} 
maka untuk membuktikan bahwa Yesus benar-benar mati maka, lambung Yesus ditikam dengan tombak.

Salib dalam bahasa Yunani adalah $\sigma \tau \alpha v \rho o \varsigma$ (stauros) yang dapat dimengerti kayu sulaan atau balok kayu yang berdiri tegak dalam konteks ini untuk mengantungkan orang hukuman. Kayu palang yang akan menggantungkan Yesus itu dinamai patibulum harus dipikul oleh terhukum sampai kepada tempat dimana penghukuman salib untuk dieksekusi. Penderitaan penyaliban sungguh sulit dibayangkan, kedua tangan pada sebatang kayu horizontal (Yoh. 20:25). Pada pukul sembilan pagi Yesus disalibkan (Mark. 15:25), dan sebagai tanda kebesaran Tuhan kegelapan menyelimuti selama tiga jam dari pukul dua belas siang sampai menjelang petang pukul tiga sore (Mat. 27: 45). Peristiwa salib yang semula dibayangkan sebagai sebuah paradoks dalam hidup Mesias, justru dengan salib itu kemesiasan Yesus menjadi jelas. ${ }^{42}$

\section{Penyaliban dalam Konsep Substitusi}

Penyaliban Kristus adalah kerelaan diri-Nya sendiri untuk menggantikan tempat orang berdosa yang harus dihukum. Yohanes 10:17 mengatakan bahwa Yesus sebagai gembala yang baik menyerahkan nyawanya untuk mengambilnya kembali. Pada satu sisi ini adalah tindakan dari seorang gembala yang baik, ${ }^{43}$ tetapi pada sisi lain nas ini menunjukkan bahwa sebagai gembala yang baik Yesus rela mati untuk mengantikan posisi domba-domba yang seharusnya mati.

Dalam konsep keselamatan, manusia yang seharusnya mati oleh karena dosa tidak jadi binasa karena ada yang mengantikannya. Kematian Yesus di kayu salib dipahami sebagai pengganti hukuman yang harus ditangung oleh manusia karena dosa. Dalam hal ini penyaliban Yesus memiliki makna bahwa Dia yang seharusnya tidak dihukum karena tidak berdosa, harus menangung hukuman untuk menggantikan posisi manusia yang berdosa.

Pada satu pihak penyaliban Yesus menjadi sebuah peristiwa yang menyedihkan karena seorang yang tidak bersalah dihukum secara mengerikan. Pada pihak lain penyaliban Yesus menjadi sebuah peristiwa yang membahagiakan bagi orang yang percaya kepada-Nya, yang mengalami substitusi hukuman sehingga oleh penyaliban ini ia dibebaskan dari kematian. Ini adalah makna salib secara teologis dalam kaitannya dengan posisi orang Kristen di mata Allah.

\section{KESIMPULAN}

Berdasarkan pembahasan di atas dapat disimpulkan bahwa hukuman salib adalah hukuman yang mengerikan, yang dilakukan oleh bangsa-bangsa bukan Yahudi. Kekaisaran Romawi yang memerintah pada masa Yesus menerapkan hukuman ini, dan Yesus adalah salah satu orang yang harus menerima hukuman ini atas desakan pemimpin-pemimpin Yahudi. Hukuman salib biasanya diberikan kepada pemberontak tetapi telah diberikan juga kepada

\footnotetext{
${ }^{42}$ Pr Eko Riyadi, Yesus Kristus Tuhan Kita (Yogyakarta: Kanisius, 2011), 59.

${ }^{43}$ Elianus Telaumbanua, "Pemimpin sebagai Gembala Berdasarkan Injil Yohanes 10:1-18," Jurnal Bijak 2, no. 1 (2018): 66-109. Band: Asih Rachmani Endang Sumiwi, "Gembala Sidang Yang Baik Menurut Yohanes 10: 1-18," Harvester, no. 4 (2019): 2, http://ejournal.sttharvestsemarang.ac.id/index.php/harvester/article/view/16.
} 
Yesus. Hal ini untuk menggenapkan bahwa Yesus disetarakan dengan pemberontak. Hukuman salib merupakan hukuman untuk menyiksa orang yang menerima hukuman itu. Hal ini untuk menggenapkan bahwa Yesus benar-benar menderita karena kejahatan manusia. Secara teologis, hukuman salib bermakna subsitusi, yaitu mengantikan manusia yang seharusnya dihukum karena dosa, tetapi hukuman itu telah ditanggung oleh seorang pribadi yang tidak berdosa, yaitu Yesus.

\section{REFERENSI}

Balasuriya, Tissa. Teologi Siarah. Jakarta: BPK Gunung Mulia, 2004.

Barclay, William. Pemahaman Alkitab Setiap Hari: Injil Matius Pasal 11-28. Jakarta: BPK Gunung Mulia, 2009.

Bergant, Dianne, dan Robert J. Karris. Tafsir Alkitab Perjanjian Baru. Yogyakarta: Kanisius, 2002.

Bermejo, Luis M. Selubung Kirmizi Jejak-Jejak Penyaliban Al Masih. Yogyakarta: Kanisius, 2008.

Chambers, Oswald. Pengabdianku Bagi KemuliaanNya. Jakarta: Duta Harapan Dunia, 2003.

Curtis, Kenneth, Stephen Lang, dan Randy Petersen. 100 Peristiwa Penting Dalam Sejarah Kristen. Jakarta: BPK Gunung Mulia, 2007.

Eko Riyadi, Pr. Yesus Kristus Tuhan Kita. Yogyakarta: Kanisius, 2011.

V. Indra Sanjaya, Pr. Yesus, Orang Nazaret, Raja Orang Yahudi. Yogyakarta: Kanisius, 2004.

Kuncahyono, Trias. Jerusalem 33 Imperium Romanum, Kota Para Nabi, dan Tragedi di Tanah Suci. Jakarta: Kompas Media Nusantara, 2011.

Lee, Jaerock. Pesan Salib. Seoul: Urum Book, 2007.

Lee, Witness. Garis-garis Besar Injil 1. Surabaya: Yayasan Perpustakaan Injil, 2001.

Lingga, Elson. Firman Hidup 69. Jakarta: BPK Gunung Mulia, 2008.

Nielsen, J.T. Tafsiran Alkitab: Kitab Injil Matius 23-28. Jakarta: BPK Gunung Mulia, 2009.

Stott, John. Kristus yang Tiada Tara. Surabaya: Momentum, 2013.

Sumiwi, Asih Rachmani Endang. "Gembala Sidang Yang Baik Menurut Yohanes 10: 118." Harvester, no. 4 (2019): 2. http://ejournal.sttharvestsemarang.ac.id/index.php/harvester/article/view/16.

Telaumbanua, Elianus. "Pemimpin sebagai Gembala Berdasarkan Injil Yohanes 10:1-18." Jurnal Bijak 2, no. 1 (2018): 66-109.

Wahono, S. Wismoady. Di Sini Kutemukan: Petunjuk Mempelajari dan Mengajarkan Alkitab. Jakarta: BPK Gunung Mulia, 2009.

Walker, Peter. In The Steps of Jesus. Yogyakarta: Kanisius, 2010.

Widyamadja, Josef P. Kebangsaan dan Globalisasi dalam Diplomasi. Yogyakarta: Kanisius, 2005.

Yewangoe, Andreas Anangguru. Agama dan Kerukunan. Jakarta: BPK Gunung Mulia, 2009.

Zaluchu, Sonny Eli. "Penderitaan Kristus sebagai Wujud Solidaritas Allah Kepada Manusia.” DUNAMIS: Jurnal Teologi dan Pendidikan Kristiani 2, no. 1 (2017): 6174. www.sttintheos.ac.id/e-journal/index.php/dunamis.

_. "Strategi Penelitian Kualitatif dan Kuantitatif di Dalam Penelitian Agama." Evangelikal: Jurnal Teologi Injili dan Pembinaan Warga Jemaat 4, no. 1 (2020): 28 38. 